\begin{tabular}{c}
\multicolumn{3}{c}{ 日本医科大学第一内科 } \\
奥村 英正 $^{\circ}$ 上田 征夫 小野沢成子 \\
菊池 恭一 越村 修 \\
東京医科歯科大学医学部第一内科 \\
野村 武夫
\end{tabular}

\title{
A PATIENT WITH PERNICIOUS ANEMIA AND MONOCLONAL IMMUNOGLOBULINEMIA (IgA K TYPE)
}

Hidemasa Okumura, MD, Yukio Ueda, MD, Shigeko Onosawa, MD, Kyoichi KIKuchi, MD and Osamu Koshimura, MD

The First Department of Internal Medicine, Nippon Medical School, Tokyo

Takeo Nomura, MD

The First Department of Internal Medicine, Tokyo Medical and Dental University School of Medicine

概要 悪性分血に単クローン性免疫グロブリン血症を伴らことは，世界中で希に報告されている，本 邦では勿論報告をみないので1例追加する.66才の主婦. 鼻出血と紫斑を主訴として入院. 理学的に は貧血, 舌萎縮, 心尖部収縮期雑音, 振動覚の軽度の異常を認めた. $\mathrm{Hb} 6.8 \mathrm{~g} / \mathrm{dl}$, 赤血球 150 万 $/ \mathrm{mm}^{3}$, MCV $133 \mu^{3}$, 白血球数 $4100 て ゙$ 過分葉を示し, 血小板数 9.1 万 $/ \mathrm{mm}^{3}$, 骨䯠は巨赤芽球と赤茅球増生像 を示した，血清 $\mathrm{VB}_{12}$ の低下，葉酸値正常，胃液の無塩酸症，Schilling test $3.6 \%$, 尿にBence Jones蛋 白陽性，血清にM蛋白 (IgA K型)を認む. 骨䯣のplasma細胞は異型性を示し，10.8\%，血清胃壁細 胞抗体陽性，内因子抗体陽性，骨にはX線学的に異常なし，単クローン性免疫グロブリン血症は無治

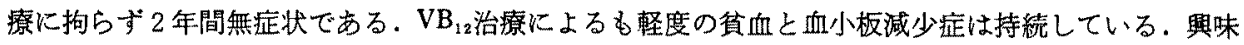
ある点は，VB $V_{12}$ 治療により一時的にIgAの減少とBence Jones蛋白の消失, IgGとIgMとテ・グロブリン の増加をみた，良性単クローン性兔度グロブリン血应も否定しえないので経過観察中である。

わが国にお゙いては正確な統計資料がなく，覀性 筫血の発生頻度の実数は不詳であるが，本貧血が 多発する北ヨーロッパ諸国，たと觉ばデンマーク から報告されている年間発生率10万対 9 , 有病率 $0.13 \%$ に比較すれば゙，はるかに低いのではない かとの印象を受ける。一方，多発性骨髄腫につい てもわが国は患者数が少なく，1955年のWHO統 計では死亡率算出の扱いを受けていない低率

〔昭和51年 2 月 14 日 第263回関東地方会推薦〕
であつた，その後, 症例数が増加する㑯向がみら れ，人口10万対年間死亡率は1963年に0.25，さら に1974年には0.65に達したが2)，Malmöに和ける 1950～1960年の人口10万対 3 に比べ3)，いぜんと して低率にとどまつている。

発生頻度が低いこれら両疾患の合併症例を経験 する機会は，とくにわが国では稀有に属する。

最近著者らは，多発性骨髄腫が疑われる単クロ ーン性免疫グロブリン血症を合併した悪性貧血の 1 症例を経験した。本邦では今回調查した限りで 
は報告が見当らない。

\section{症 例}

患者：66才, 主婦.

家族歴：父が53才で胃癌で死亡．兄に慢性胃 炎，弟に胃潰瘍がある。

既往歴：16才右湿性胸膜炎，25才か560才ま で気管支喘息，38才低血圧といわれ，50才虫垂 炎,な打閉経は49才である。

現病歴：昭和50年 9 月 5 日鼻出血があり約 30 分で止血した. しかし同月中に鼻出血が $5 \sim 6$ 回 つづいた. 10月 3 日また鼻出血があつたので, 某 院耳鼻科を受診し，内科受診をすすめられて来 院, 昭和50年10月 6 日当科入入院した.

入院時現症：身長 $144.5 \mathrm{~cm}$, 体重 $46.5 \mathrm{~kg}$. 前 胸部・左右上下肢に紫斑を認めた。脈拍 80 , 整. 血圧120/54. 眼䀫 結膜貧血著明, 眼球結膜に黄疸 なし. 舌は萎縮状. 口唇, 爪にチアノーゼなし. 甲状腺ふれず，頝部腋窩などりンパ節を触知せ ず. 肺肝境界第 6 肋間, 心尖部に収縮期雑音を聴 取した。腹部は平坦, 回盲部に手術痕あり。鼓 腸, デンファンス, 腫瘤など異常所見なし、肝, 脾, 腎はふれず. 四肢の運動障害なく, 腱反射正 常で, 病的反射はなかつた. 両下肢の知覚は, 振 動覚の減弱の他は特に異常なかつた. 軽度の浮腫 を下肢に認めた。

入院時検査成績：血液検査の結果は表 1 亿示 すごとく, 再生像に乏しい高度の大球性高色素性 貧血があり, 血小板子減少した. 末梢血液塗抹標 本では赤血球の大小不同変形症が目立ち, 少数の 赤芽球を認め, 好中球核の過分葉を証明した注 か，形質細胞を散見した。

骨髄には多数の巨赤芽球と少数の巨大後骨髄球 を認め,さらに形質細胞の増加を認めた（表 1 ）. 形質細胞百分比は $10.8 \%$ であるが，分布が不規則 で集合する傾向がみられ，個々の形態をみると一 般に大型で，核は大きな核小体を 1 個有し，クロ マチン核網は緘細で，しばしば多核のものを認め るなど，強い異型性が目立つた（図 1 ).

表 2 はその他の一般検査成績で, 主な異常は血
表 1 . 血液像ならびに骨㕹像

\begin{tabular}{|c|c|c|c|}
\hline 淮 & 像 & 荼 & \\
\hline 办衈球数 & $150 \pi / \mathrm{mm}^{3}$ & 仿核細胞数 & $18.07 / \mathrm{mm}^{3}$ \\
\hline へモグロビン & $6.8 \mathrm{~g} / \mathrm{u}$ & 汾比 & \\
\hline ヘマトクリット & $20 \%$ & 骨箱将球 & $0.2 \%$ \\
\hline $\mathrm{MCV}$ & $133[1$ & 好中性前胡留这球 & 2.4 \\
\hline $\mathrm{MCH}$ & $45 p g$ & 好中性材能球 & 6.0 \\
\hline $\mathrm{MCHC}$ & $34^{\circ} \circ$ & 好中性後什此球 & 6.0 \\
\hline 絧办组球 & $24 \%$ & 好中性掉颃核球 & 11.0 \\
\hline IfIL小板数 & $9.1 万 / \mathrm{mm}^{3}$ & 好中性分桇核球 & 17.2 \\
\hline 白血球数 & $4100 / \mathrm{mm}^{3}$ & 好洨球 & 0.8 \\
\hline 白显球百分比 & & 好盗悲球 & 0 \\
\hline 捈状核好中球 & $6 \%$ & 半 球 & 2.6 \\
\hline 2 分辚核好中球 & 11 & リン八球 & 3.6 \\
\hline 3 分梁校好中球 & 12 & 形岓縕胞 & 10.8 \\
\hline 4 分种核好中球 & 11 & 絒科縕胞 & 1.2 \\
\hline 5 分亲核好中球 & 3 & 前办牙球 & 1.0 \\
\hline 6 分莱㤥好中球 & 1 & 染染性:正小程球 & 2.6 \\
\hline 好般球 & 7 & 多染性正小财球 & 9.6 \\
\hline 好㷪少球 & 1 & 正無性:正小掝球 & 6.2 \\
\hline 菓 球 & 6 & 青吹性巨办讶球 & 5.0 \\
\hline リン八球 & 42 & 多染性巨办沙球 & 8.8 \\
\hline 办讶球 & $(+)$ & 正染性巨办雅球 & 5.0 \\
\hline 形篮細胞 & $(+)$ & $\mathrm{M} / \mathrm{E}$ & 1.62 \\
\hline
\end{tabular}

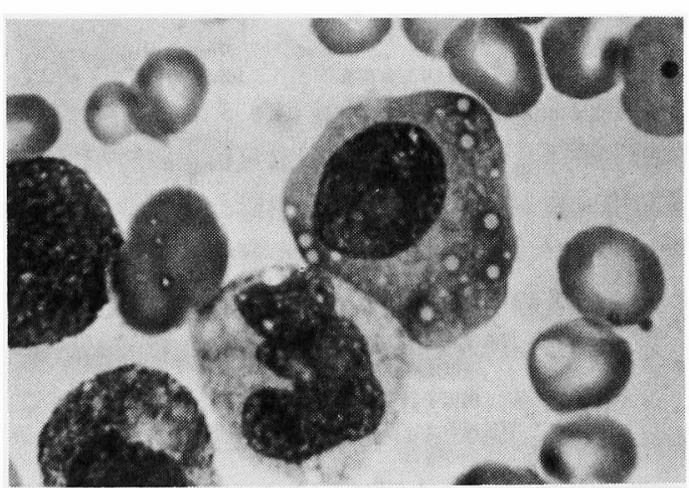

図1。骨䯣標本にみられた異型形質細胞と巨大 後骨䯣球

沈促進, 尿蛋白強陽性および血清LDH上昇であ つた．凝血学的には異常所見がなかつた。

表 3 は巨赤芽球性貧血にかんする検查成績で, 血清ビタミン $\mathrm{B}_{12}$ は $100 \mathrm{pg} / \mathrm{ml}$ 以下に低下，尿中メ チルマロン酸排泄は明らかに増加し, L-バリン負 荷によりいつそう増量し, ビタミン $\mathrm{B}_{12}$ 欠乏の存 在が明らかとなつた. 一方, 血清葉酸は正常値, ヒスチジン負荷試験の結果も陰性で, 葉酸欠乏は 否定された。次に，ビタミン $\mathrm{B}_{12}$ 単独投与による Schillingテストは 24 時間尿中排泄率 $3.6 \%$ と低值 を示し, 血清抗胃抗体の検索では内因子抗体, 壁 


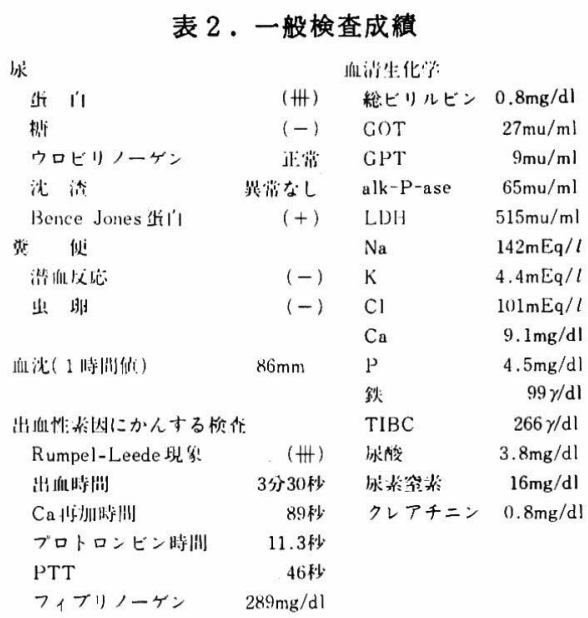

\begin{tabular}{|c|c|}
\hline 血消ビ タミン B 12 & $98 \mathrm{pg} / \mathrm{ml}$ \\
\hline 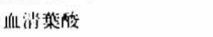 & $14.6 \mathrm{ng} / \mathrm{ml}$ \\
\hline \multicolumn{2}{|l|}{ 戚中メチルマロン唼 } \\
\hline 鳀街前 & $97 \mathrm{mg} /$ 日 \\
\hline L-バリン目街後 & $165 \mathrm{mg} /$ 日 \\
\hline \multicolumn{2}{|l|}{ ヒスチジン負荷試野 } \\
\hline 尿中FIGLU & $10 \mathrm{mg} / \mathrm{dl}$ \\
\hline 尿中ウロカニン枱 & $10 \mathrm{mg} / \mathrm{dl}$ \\
\hline \multicolumn{2}{|l|}{ Schilling テスト } \\
\hline 内因子 $(-)$ & $3.6 \%$ \\
\hline \multicolumn{2}{|l|}{ IIlL中抗胃抗体 } \\
\hline 跣細胞抗体 & $(+)$ \\
\hline 内因子抗体 & $(+)$ \\
\hline \multicolumn{2}{|l|}{ 因液検代(ヒスタミン法) } \\
\hline 遊離盐酸 & $(-)$ \\
\hline 内因子活性 & $(-)$ \\
\hline 胃透視およU胃内视鏡 & 娄艄胜胃炎 \\
\hline
\end{tabular}

細胞抗体のいずれる陽性, さらに胃液中の内因子 活性欠如を証明した。すなわち，本症例のビタミ ン $B_{12}$ 欠乏は内因子欠如によることが明らかとな つた。

血清蛋白の分析結果は図 2 に示すごとく，血清 総蛋白は正常であるが，電気泳動によりslow $\beta$ 域に $\mathrm{M}$ 蛋白らしい峰を認め, 免疫電気泳動により このパラプロティンはIgA-Kと判明した. 免疫グ ロブリン定量の結果は，IgAが 明らかな増加を示 乙，他方，IgGは正常下界，IgMは明らかに減少 を示した，尿中にはK型Bence Jones蛋白を検出， 尿蛋白の 1 日排泄量は $0.9 \sim 1.8 \mathrm{~g}$ であつた。な お，全身骨格系をX線学的に調べたが，骨融解像 は証明されなかつた。

\begin{tabular}{llll} 
& & & \\
綕蛋白 & $7.3 \mathrm{~g} / \mathrm{dl}$ & \multicolumn{2}{c}{ 疫グロブリン } \\
アルブミン & $57.3 \%$ & IgG & $1000 \mathrm{mg} / \mathrm{dl}$ \\
$\alpha_{1}$-グロブリン & $2.5 \%$ & IgA & $1040 \mathrm{mg} / \mathrm{dl}$ \\
$a_{2}$-グロブリン & $5.7 \%$ & IgM & $15 \mathrm{mg} / \mathrm{dl}$ \\
$\beta$-グロブリン & $10.2 \%$ & & \\
M蛋白 & $10.2 \%$ & & \\
$\gamma$-グロフリリン & $14.1 \%$ & &
\end{tabular}

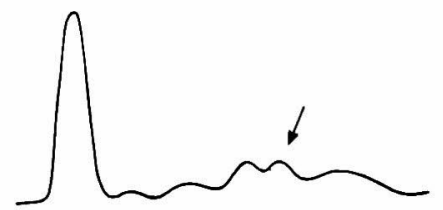

因 2-1．血清および尿蛋白像
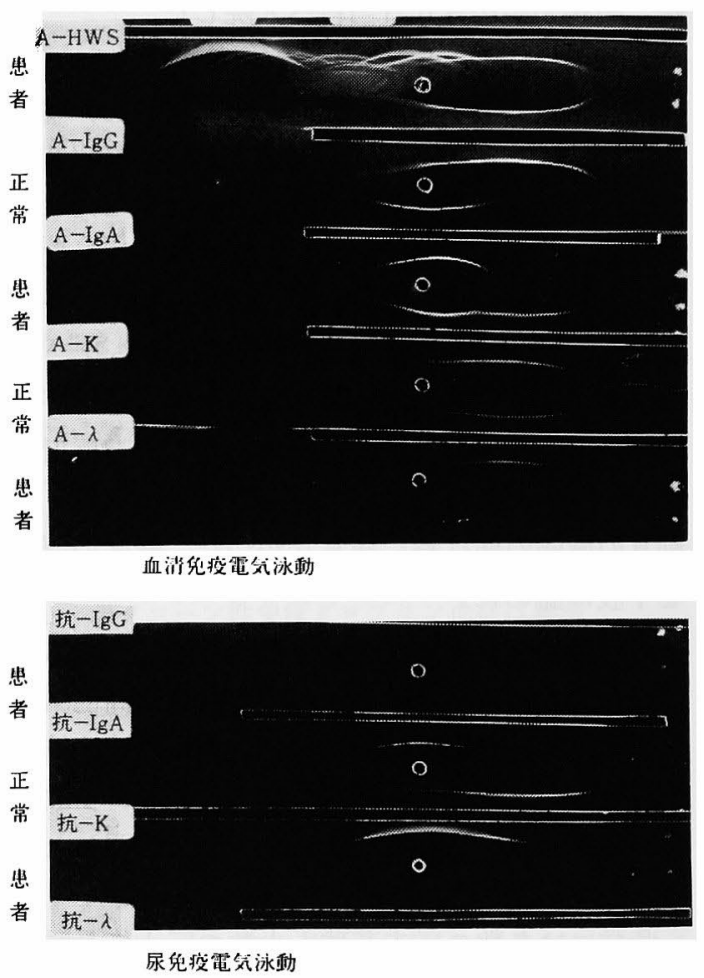

因 2-2, 血清および尿の免疫電気泳動

経過：11月13日, Schillingテストのためビタ ミン $\mathrm{B}_{12} 1000 \mu \mathrm{g}$ を注射したところ，一過性の弱い 網赤血球増加反応を呈したのち，へモグロビン濃 度は徐々に上昇に転じた．以後，ビタミン $\mathrm{B}_{12}$ 注射 を 1 回追加したのみで12月 3 日に退院したが，翌 

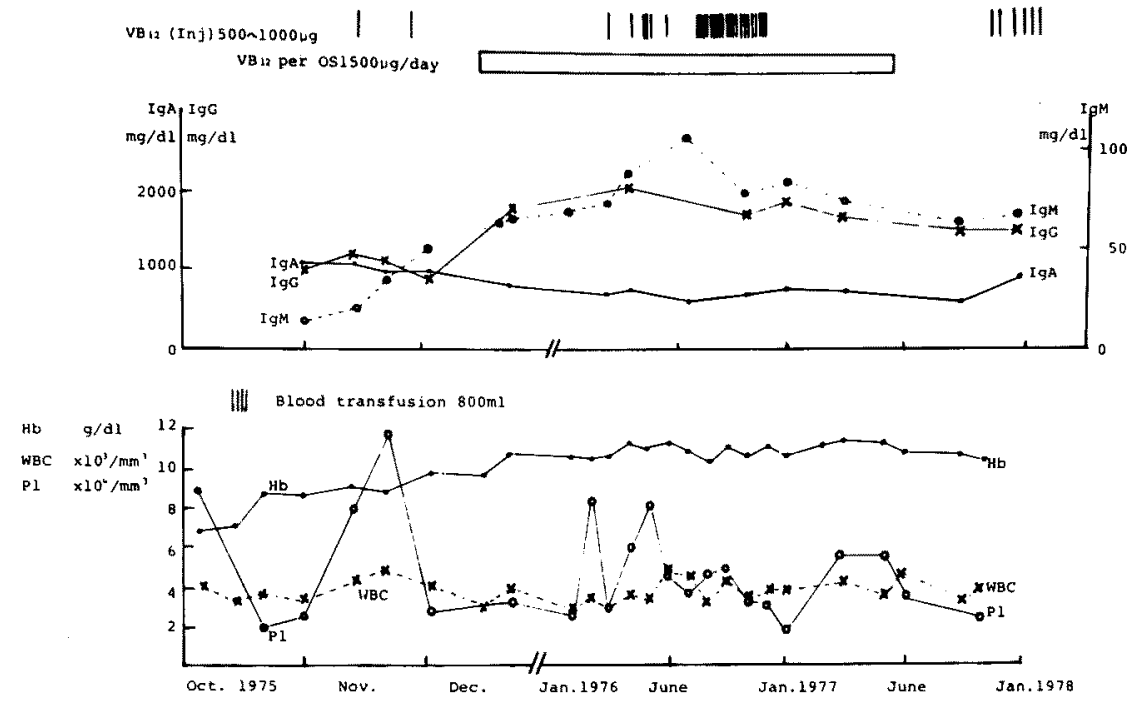

图 3.経通

51年 1 月 12 日外来受診時にはへモグロビン濃度が $10 \mathrm{~g} / \mathrm{dl}$ を超えていた，続いて，ビタミン $\mathrm{B}_{12} 1$ 日 $1500 \mu \mathrm{g}$ 経口的に連用したが，へモグロビン濃 度は $11 \mathrm{~g} / \mathrm{dll}$ に達しなかつたため，4月よりビタ ミン $B_{12} 1$ 回500〜1000 $\mu \mathrm{g}$ を月 $1 \sim 2$ 回筋注, さら に一時は隔日に注射を反復した。しかし，へモグ ロビン濃度はいぜんとして $11 \mathrm{~g} / \mathrm{dl}$ 前後のまま 2 年 余を経過，今日に及んでいる。また，白血球は終 始3000〜 4000と少なく, 血小板むビタミン $\mathrm{B}_{12}$ に 反応を示ざす，2〜8万を動摇している（図 3 ）.

一方, 単クローン性免疫グロブリン血症の経過 であるが，血清蛋白電気泳動では常にslow $\beta$ 域 KM峰を証明, 免疫電気泳動像る初診時と変りが ない. 危疫グロブリンの経時的変動は図 3 のごと くで，IgAはビタミン $\mathrm{B}_{12}$ 投与開始後に減少し，汇 注600〜800mg/dlのレベルに維持され，他方，IgG はビタミン $\mathrm{B}_{12}$ 療法開始後に上昇に転し，変動域 はおよそ500〜2000 $\mathrm{mg} / \mathrm{dl}$ と広いが，初診時に比べ 高値を呈している.IgMの変動すIgGと類似の 傾向を示したが，常に低值である．尿中Bence Jones蛋白はビタミン $\mathrm{B}_{12}$ 㙩法開始後も陽性にとど まり，初診後 1 年を経過したころ一時陰性を呈し た時期があつたが，その後再び陽性に転じ, 現在
に至つている.

なお初診から約 1 年後に実施した骨䯣検査で は，形質細胞百分比は $11 \%$ と变らず，形態学的に はやはり強い異型性が認められた。一方，巨赤芽 球，巨大後骨髄球などのビタミン $\mathrm{B}_{12}$ 欠乏を物語 る所見は完全に消失していた。この時期にも，X 線学的に骨融解像は証明されなかつた。

\section{考案}

本症例の診断について，諸検査成績から悪性盆 血は問題がないところであるが，単クローン性免 疫グロブリン血症を悪性と断定するのは，はばか られる、すなわち，IgA以外の免疫グロブリンの 著減所見を欠き，IgAパラプロティン量が比較的 少なく, しかも2 年余の経過観察中増量する気配 を認めず，骨融解像が証明されないなど，多発性 骨髄腫としては非定型的な諸特徵を有しているか らである。

しかし，骨髄の形質細胞は，百分比が約 $10 \%$ に すぎなくても，その大多数が著しい異型性を呈 し，尿中Bence Jones蛋白がほとんど常に陽性で ある事実は，多発性骨髄腫の診断を支持する。さ らに，ビタミン $\mathrm{B}_{12}$ 療法による貧血の回復が不完 全で, 白血球減少症および血小板減少症が改善し 
表 4. 悪性筫血と単クローン性免疫グロプリン血症の合併例

\begin{tabular}{|c|c|c|c|c|c|c|c|c|c|}
\hline 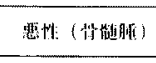 & 毞秋笈代 & $\mathrm{H}:$ & M犆' & $1-$ th & 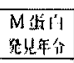 & $\begin{array}{l}34 \div 7 \\
\text { 试 }\end{array}$ & 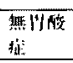 & 瞓山扎推 & this \\
\hline \multirow[t]{3}{*}{ Larsson } & \multirow[t]{3}{*}{1962} & $F$ & G & ND & 69 & + & + & $\mathrm{NIJ}$ & - \\
\hline & & M & G & ND & 37 & + & ND & ND & + \\
\hline & & $\mathrm{F}$ & $\mathrm{C}$ & ND & 87 & - & + & $\mathrm{NO}$ & - \\
\hline Fraser & 1969 & $\mathrm{~F}$ & G & $\lambda$ & 68 & + & + & $\mathrm{CPC}( \pm) \mathrm{F}( \pm)$ & + \\
\hline Gomez & 1970 & $\mathrm{~F}$ & A & k & 43 & + & + & NI) & + \\
\hline Hruicirz & 1970 & M & A & $\mathrm{k}$ & 67 & + & + & $\mathrm{CPC}(+\mathrm{HF}(+)$ & - \\
\hline \multicolumn{9}{|l|}{ 良性 } & 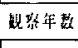 \\
\hline \multirow[t]{3}{*}{ Larson } & \multirow[t]{3}{*}{1962} & M & M & ND & 54 & ND & + & ND & 6 \\
\hline & & $\mathrm{F}$ & A & ND & 79 & + & + & ND & 2 \\
\hline & & $\mathrm{F}$ & G & ND & 68 & - & ND & ND & 1 \\
\hline Waldenström & 1964 & F & G & ND & 67 & + & + & ND & 7 \\
\hline Bichel & 1964 & F & G & ND & 68 & ND & + & ND & 16 \\
\hline van Dommelen & 1964 & $\mathrm{~F}$ & M & ND & 86 & - & + & ND & \\
\hline Axelsson & 1966 & & & & & & & & \\
\hline \multirow[t]{4}{*}{ Hallen } & \multirow[t]{4}{*}{1965} & $\mathrm{~F}$ & $\mathrm{G}$ & No & 67 & ND & ND & ND & \\
\hline & & M & $\mathrm{o}$ & ND & 74 & No & ND & ND & \\
\hline & & $\mathrm{F}$ & A & No & 65 & & & & \\
\hline & & $\mathrm{F}$ & A & ND & 81 & & & & \\
\hline Conn & 1968 & & G & ND & & & & & 4 \\
\hline Cooke & 1969 & & 0 & No & & & & & \\
\hline Kjeldsen & 1969 & M & $G$ & $\mathrm{k}$ & 73 & + & + & ND & \\
\hline Ginsberg & 1970 & $\mathrm{~F}$ & G & $\mathrm{k}$ & 43 & + & + & ND & \\
\hline Selroos & 1973 & M & G & k & 78 & + & & $\mathrm{GPC}(+)$ & 2 \\
\hline \multirow[t]{2}{*}{ Burner } & 1976 & M & A & K & 69 & + & + & $\mathrm{CPC}(-) \mathrm{IF}(-)$ & \\
\hline & & M & M & ND & 66 & + & + & $\mathrm{GPC}(+) \mathrm{IF}(+)$ & 11 \\
\hline Present case & 1978 & $\mathrm{~F}$ & A & $\mathrm{K}$ & 66 & + & + & $\mathrm{GPC}(+\mathrm{HF}(+)$ & 2 \\
\hline
\end{tabular}

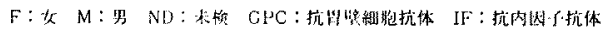

ない点も，骨髄において悪性増殖過程が進行して いると考光た方が説明をつけやすい。

良性単クローン性免疫グロブリン血症の最終的 診断は，定義上，長年月の経過を追跡して始めて 可能なわけで，現在のところ進行性を欠くとはい え,悪性致候をいくつか備えた本症例において, 良 性の診断を下すのは控えるべきである。本症例で は多発性骨髄腫への進展が強く予測されるが，さ し当つては，単クローン性免疫グロブリン血症と い5にとどめておくのが最も妥当と考察される。

悪性貧血と単クローン性免疫グロブリン血症の 合併は，1954年Mandema ${ }^{4}$ によつて報告されてい るが，この論文には詳細な記載を欠いており，両 病態の合併を最初に詳しく論じたのはLarsson ${ }^{5)}$ ある．彼は悪性貧血と多発性骨髄腫の合併 6 例标 よび良性単クローン性免疫グロブリン血症の合併 3 例, 計 9 例を集めているが，その中には悪性貧 血の疑診例も含まれている，その後，かかる合併
症例の報告が散発的にみられ，文献上涉椫しえた 症例を，悪性 ${ }^{67) 8)}$ と良性単クローン性免疫グロブ リン血症"別にまとめると，表 4 のごとくである. 血清 $M$ 蛋白の出現率は加令とともに上昇し， 60 才以上では，本邦で1\% ${ }^{10)}$ ，スエーデンでは $2 \%{ }^{11)}$ の頻度で検出されるという．またこの年令層には 悪性貧血が好発することを考克合せると，多発性 骨髄腫はともかく, 良性単クローン性免疫グロブ リン血症を伴う悪性貧血の報告例数は意外に少な い。しかし良性単クローン性免疫グロブリン血症 は通常無症状であり，また悪性貧血患者において 常に血清M蛋白の検索が行なわれるとは限らない ため，見逃がされていることを考虑しなければな らない。したがつて，この合併を両疾患が偶然同 一個体に発生した結果にすぎないと片附けずに， 病因論上の関連について考察を試みるべきであろ 5 .

第一に，悪性貧血か単クローン性免疫グロブリ 
ン血症のいずれか一方が，他方の原因となるので はないかとい5点については, 発症の順序が手掛 りとなろう。ところが, 文献上では悪性貧血の経 過中に血清M蛋白が出現した例, 逆に単クローン 性免疫グロブリン血症が先行した例，さらに本例 の如く両者が同時に発見される場合もあり，一定 の順序はみられない。ところで, 悪性貧血患者に おける血清M蛋白の出現率が，一般人に比べ高い といら報告は見当らないか゚，一方血清 $\mathrm{M}$ 蛋白陽性 者間では, 一般人に比べ, 悪性貧血の発生率が高 いのではないかと示唆する報告9がある。したが つて, 単クローン性免疫グロブリン血症を基に悪 性䆩血が発生する機転を考えさせるが，結論をら るには広範なる疫学的調査を必要としょう。

第二に，悪性貧血と単クローン性免疫グロブリ ン血症が共通の原因に基づく可能性はどうかとい 5点である．悪性貧血を自己兔疫性疾患とみなす 学説があり, 一方, 血清M蛋白は免疫機構に生じ た異常の表現の一つであると理解される．血清 $\mathbf{M}$ 蛋白は，慢性関節リウマチ, SLE，多発性動脈炎 なとの自己免疫疾患に伴つて出現することが知ら れている。悪性貧血が自己免疫疾患の範疇に入る のであれば，両疾患が合併しても不思議はないこ とになる.免疫装置に生じた何んらかの欠陥が， 一方では悪性貧血を，他方では血清M蛋白の発生 をらながしたと説明することになるが，その欠陥 の本態は不明といわざるをえない。

最後に，本例では悪性貧血に対すビタミン $\mathrm{B}_{12}$ 療法によつて，血清免疫グロブリン濃度に一見変 化を生じたように思われる。すなわち，IgGおよ びIgMの増加とIgAの減少である. Selroosら ${ }^{12)}$ 11例の悪性貧血患者について治療前後の免疫グロ ブリンを測定し，治療によつてIgGおよびIgMが 増加し，IgAは減少したと報告している。むつと も，いずれも正常範囲内の変動にとどまつており， しか子変動幅当狭く, 平均してIgG $50 \mathrm{mg} / \mathrm{dl}, \mathrm{IgA}$ 38mg/dl, IgM 7mg/dlの増減にすぎない。われわれ の症例では，Selroosらの観察と，本質的には同一 の傾向を呈したのであるが，变動幅がかなり大き いように思われる。本症例のごとくビタミン $\mathrm{B}_{12}$ 投与前に各免疫グロブリンが增加, るしくは減少 している場合には，治療の影響が誇張されるため
かも知れない．本例の単クローン性免疫グロブリ ン血症の本態が悪性であるとすれば，ビタミン $\mathrm{B}_{12} か ゙$ 腫埸性 IgA産生クローンの細胞増殖を阻止し たと解积され，興味深く思われるが，この点にか んしては，さらに今後の経過追跡の必要がある。

\section{結 語}

悪性貧血にIgAK型単クローン性免疫グロブ リン血症を合併した66才の女性例を報告した。2 年余にわたつて経過観察中であるが，骨髄腫と断 定出来ないが，悪性と考兄られる所見をいくつか 有している。

\section{文献}

I) Pedersen $\mathrm{AB}$ and Mosbech J: Morbidity of pernicious anaemia. Acta Med Scand 185: $449,1969$.

2)人口動態統計。厚生省大臣官愿統計調查部編， 厚生統計協会, 1975 .

3) Waldenström J: Diagnosis and Treatment of Multiple Myeloma. Grune and Stratton, New York, 1970.

4) Mandema E and Wildervanck L S: La maladie de Kahler (Myélomes multiples) chez deux sceurs. J Génét Hum 3: 170, 1954.

5) Larsson SO: Myeolma and pernicious anemia. Acta med Scand 172: 195, 1962.

6) Fraser KJ: Multiple myeloma and pernicious anemia. Med J Aust 56: 298, 1969.

7) Gomez AF and Hurley JB: Multiple myeloma and pernicious anemia. West Virginia Med J 66: 38, 1970.

8) Hrncir $Z$, et al: Coincidence of pernicious anemia and IgA-K myeloma. A clinical model of the relation between autoimmune disease and tumour from immunocomponent tissue. Neoplasma 17: 197, 1970.

9) Burnier E, et al: Nonmalignant monoclonal immunoglobulinemia, pernicious anemia and gastric carcinoma. Amer J Med 60: 1019, 1976.

10) Takatsuki K: Plasma cell myeloma and related diseases in Japan: Clinical and immunochemical studies on $\mathbf{M}$-components. Acta Haematol Jpn 31: 636, 1968.

11) Axelsson U, et al: Frequency of pathological proteins (M-component) in 6995 sera from an adult population. Acta med Scand 462: (suppl) 1: 1966

12) Selroos $\mathrm{O}$ and von Knorring J: Immunoglobulins in pernicious anemia (including a report on a patient with pernicious anemia, IgA deficiency and M-component of Kappa type IgG). Acta med Scand 194: 571, 1973. 